\title{
Challenges Faced by English Teachers: Implementation of Higher Order Thinking Skills (HOTS) in Designing Assignments in East Indonesia
}

\author{
Aprilia Arnis Ginting $^{1}$, Paulus Kuswandono ${ }^{2}$ \\ Sanata Dharma University, Yogyakarta, Indonesia ${ }^{1,2}$ \\ Email: ginting.arnis@gmail.com ${ }^{1}$ \\ Email: kus@usd.ac.id ${ }^{2}$
}

\begin{abstract}
Higher Order Thinking Skills (HOTS) have been implemented in Indonesia as part of the $21^{\text {st }}$ Century learning to face Industry Revolution 4.0. The implementation of HOTS is also fully supported by the Minister of Education (MoE) considering, that those critical thinking skills are fundamental to facilitate the graduates with problem-solving and decision making. Nevertheless, very limited references discuss English teacher perceptions on the implementation of HOTS in terms of designing assignments for English learning. As HOTS implementation cannot be separated from the teachers' role, the teachers are supposed to exhibit good skills in designing assignments by integrating HOTS aspects. The research question and objective of this study relate to the following issue: what are the challenges of designing HOTS assignments as perceived by English teachers in East Indonesia? The research participants were twenty Senior High School English teachers in Flores Island, East Nusa Tenggara, Indonesia. The researchers developed our research instruments, namely questionnaire, class observation, Focus Group Discussion (FGD), and interview. The data were subsequently cross-checked with the results from each instrument to triangulate the data consistency. This study indicated that the participants had a positive perception of designing HOTS assignments. However, the participants also faced challenges in its implementation. They were divided into three categories, namely: teachers' knowledge, teachers' preparation, and students' limited ability. These findings also provided the reasons why English teachers need to construct positive awareness on the importance of HOTS in designing assignments to improve the quality of the English learning process.
\end{abstract} Keywords: English teachers, Higher Order Thinking Skills (HOTS, Designing assignment, East Indonesia

\section{INTRODUCTION}

According to the World Economic Forum, 65 percent of students who are now in elementary school will work in professions that do not exist today. Hence, one of the Education challenges to anticipate future job market is providing spaces to develop critical-thinking skills in schools. Critical thinking skill is indispensable for giving exposure to reflect and focus on what to do by giving rational Thinking (Norris \& Ennis, 1989). 
This skill is suitable for the condition of $21^{\text {st }}$ century learning. From that condition, tactful strategies to prepare children to face the world demand are highly needed. For this reason, the Ministry of Research, Technology, and Higher Education stated that HOT questions could be the appropriate stimulus and means to achieve that goal. To respond to this issue, the Ministry of Education and Culture continued its program to include HOTS in the 2019 national examination.

Higher Order Thinking Skills (HOTS) have been investigated by many researchers since it is an appropriate topic for $21^{\text {st }}$-century learning. Higher-Order Thinking is a skill combination of a transfer, critical thinking, and problem-solving (Brookhart, 2010). Faravani \& Atai(2015)defined Higher Order Thinking Skills (HOTS) as a problem solving and critical thinking activities. In the process of $21^{\text {st }}$ century learning activities, teachers play a crucial role in implementing HOTS for achieving the $21^{\text {st }}$ learning goal. This goal can be quite laborious to achieve, considering that Indonesia was ranked at $62^{\text {nd }}$ from 70 countries as reviewed by PISA in 2015. The low PISA result of Indonesia is certainly caused by several factors. One of the factors is identified by some researchers, arguing that the Indonesian students are poorly trained in solving contextual problems in the form of assignments (Faravani \& Atai, 2015), which is essentially taught in the Higher Order Thinking Skills learning process. During the learning process, HOTS can help students and teachers to make connections between concepts and facts so that they are able to bring up new solutions (Thomas \& Thorne, 2014). That is why students exerting critical thinking will form a process of ability to manage strategies in solving the problem(Wang \& Seepho, 2017). This concept is helpful for students to improve their critical thinking and problem-solving skills in the form of assignments. Furthermore, Sulaiman et al., (2017)classified in their research that teachers need to in still HOTS aspects to help students in encouraging deeper Thinking through higherorder activities. Besides, teachers should be able to apply the strategies in designing higher-order assignments.

The educational development cannot be separated from the world demands. Yoke, Hasan, Jangga, \& Kamal(2015)said that the students in this era need Higher Order Thinking Skills knowledge early to prepare them in facing the $21^{\text {st }}$ century demands. To prepare this demand, the teaching-learning process is expected to have an education transformation related to the teaching and learning system, one of which is by designing HOTS assignments. The transformation of teaching-learning process has been linked to the teachers' knowledge about HOTS. Hadi, Retnawati, Munadi, Apino, \& Wulandari (2018)stated in their research on teachers' knowledge about HOTS, which can be used as a strategy to get a successful education, especially for teachers' quality improvement. Hadi et al., (2018) also stated that HOTS is the main key for achieving a successful education by implementing various $21^{\text {st }}$-century innovative learning models. Gilboy, Heinerichs, Pazzaglia, $\&$ Chester (2014)mentioned that there are three components of HOTS, which are led by the framework of $21^{\text {st }}$-century learning. They are (1) knowledge and innovation skill (2) life and job skills (3) media, information and technology skills. Those three components are needed to achieve the main goal of $21^{\text {st }}$-century learning. It is correlated to the teaching and learning process in class, which focus on students centered and project based since those activities are able to develop students' skills in facing HOTS demands (Şener \& Tü, 2015).

Teachers should be able to design HOTS assignments in order to achieve successful Education. To attain successful educational achievement, it is not always based on an up-todate curriculum, but rather on how to implement the teaching and learning process in the classroom (Purnomo, Kaur, \& Noor, 2018). In 
fact, teachers still find challenges in implementing and preparing the learning materials which are covered by HOTS. This fact is the same as stated by Ganapathy, Kaur, Singh, Kaur, \& Kit(2017)on their research about teachers' perceptions in implementing HOTS. The challenges of implementing HOTS faced by the teachers came from the students' real-life skills. In fact, if there is no intervention in the education process, students are not ready to compete in the global labor market in the future. Therefore, it is really high time for teachers to play their important role in preparing the students to face future challenges (Ganapathy \& Kaur, 2014). By seeing this condition, teacher professional development is needed to hone teachers' competences in comprehending the instructional method to face the $21^{\text {st }}$-century learning era (Gutierez, 2016). That is why teachers need to improve their skills in developing a learning strategy and teaching process in $21^{\text {st }}$-century learning, especially in designing assignments. One of the strategies is empowering HOTS which consists of critical thinking, creativity, collaboration, and communication. These aspects are expected to develop acknowledgment as fundamental elements of the school educational program.

Higher Order Thinking Skills have been implemented since the formation of K.13 in Indonesia as part of the $21^{\text {st }}$ century learning to face Industry Revolution 4.0. Nevertheless, there are only a few references that examine the topic of Higher Order Thinking Skills, specifically those who discuss English teacher perceptions on designing assignments based on HOTS. Still, none has raised the issue of designing English assignments in the scope of Indonesian Education, particularly within the context of the eastern part of Indonesia. The development of HOTS learning for teachers, especially in terms of designing material, has been the main educational goal in many countries (Yen \& Halili, 2015). The designing HOTS materials can be developed by selecting the appropriate tasks. Task selection is needed to improve students' abilities, which are correlated to Higher Order Thinking Skills (Faravani \& Atai, 2015).HOTS is one of the important components that must be included in the teaching and learning process (Retnawati et al., 2018). However, most of the teachers still found obstacles to implement HOTS in the process of teaching and learning since teachers' knowledge of HOTS is still low. Setiawan, Anggani \& Bharati (2018)showed on their research that most teachers need to improve their competence and understanding of HOTS, particularly for designing activities related to teachers' creativity and critical thinking. It was found that teachers faced challenges to develop learning tasks in facilitating HOTS, which denotes that the teachers' ability to apply HOTS in the learning and teaching process is still quite limited(Ganapathy et al., 2017).

Higher Order Thinking Skills (HOTS) have been included in some schools' curriculum in several countries (Assaly \& Smadi, 2015), including Indonesia through K.13. One element of $\mathrm{K} .13$ is strengthening the learning process. Through strengthening the learning process, it is hoped that it can improve the quality of learning to become more effective, efficient, steady, and meaningful. By implementing Higher Order Thinking Skills (HOTS) at schools, many efforts are used to prepare teachers in designing activities related to the 21st-century learning framework (Zahrani \& Elyas, 2017). In this context, the researchers discuss the perceptions of Senior High School English teachers in East Nusa Tenggara (Flores Island) regarding the challenges they face in designing HOTS assignments. In fact, based on an anecdotal observation prior to the research, there are still many teachers who did not understand the importance of HOTS. Hence, teachers need to learn how to design assignments to the students by seeing the students' needs. There are challenges that are likely unavoidable for 
teachers to implement HOTS as their strategy to make their methods suitable for $21^{\text {st }}$-century learning. Cultural properties and local values are the strongest ones that teachers have to cope with. It is by no means eradicating whatever has been considered ideal in the society where the learning process takes place, but rather, it is about how teachers can synchronize their HOTS with cultural properties and local values to make them blend and not collide. Based on the background given, one question that served to guide this research is: what are the challenges of designing HOTS assignments as perceived by English teachers? This question is the central issue and the aim of the investigation for this paper.

\section{METHOD}

To answer the research question, the researchers applied the mixed methods by clustering the qualitative and quantitative data result. This method is in line with Creswell (2014) who argue that mixed method focuses on the combination between qualitative and quantitative in a research study. The researchers conducted a concurrent triangulation strategy (see Figure 1 below). Creswell and Creswell (2017) remark that the model of the mixed method "generally uses separate quantitative and qualitative methods as a means to offset the weaknesses inherent within one method with the strengths of the other" (p. 213). The researchers decided to implement mixed methods to ensure the effectiveness of gaining rich data of the participants.

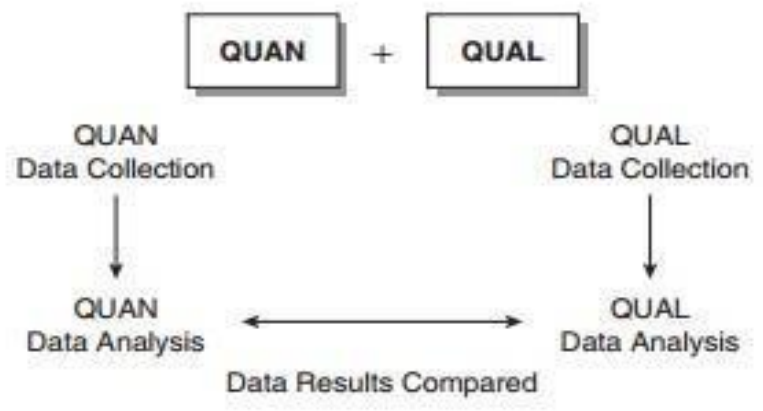

Figure 1: Concurrent Triangulation Strategy (Creswell \& Creswell, 2017)
This research adopted a "sequential explanatory mixed methods" design (Creswell, 2014) that aims to identify the English teacher perceptions on the implementation of HOTS in designing assignments. This method used two phases: (1) the researchers collected quantitative data, analyzed the result, and then (2) used the results to plan the qualitative phase (Creswell, 2014). In the first phase of the research, quantitative data was collected by inviting twenty Senior High School English teachers from different schools using randomized sampling to fill the questionnaire. A total of ten items of statements in the questionnaire were used in this study to identify the challenges on designing HOTS assignments as perceived by English teachers in Flores, ranging from strongly disagree to strongly agree. The second phases of the research were class observation, Focus Group Discussion (FGD) and interview to get more indepth explanation of the findings. The interview was conducted with eight volunteers who represented teachers' different insight on the implementation of Higher Order Thinking Skills in designing HOTS assignments.

To ensure the data validity that would be conveyed at the finding, the researchers used methodological triangulation, which involved the use of multiple methods to find the research finding. The result from the questionnaire, class observation, Focus Group Discussion (FGD) and interviews could be compared to find similar data; then, the data validity was established.

\section{RESULT AND DISCUSSION Result}

Throughout this research paper, the results of this study were projected and expected to get more specific pictures of teachers' perceptions about designing assignment which integrate Higher Order Thinking Skills (HOTS) within the activities and its strategy to achieve the main goal of Education. Therefore, this research paper was 
intended to investigate the challenges of Flores teachers' in designing HOTS assignments which they have experienced. There were three main points from the result that will be elaborated in this section.

\section{Teachers' Knowledge}

Teachers' knowledge was one of the challenges most often encountered by participants in designing HOTS assignments. Around $60 \%$ out of $100 \%$ of participants shared the same opinion that the teachers' knowledge was a tough challenge for these participants. Lack of HOTS information distribution was one of the challenges for the participants. Moreover, when the participants explored HOTS information from books and internet, the participants said that the use of technology was also a considerable challenge for them as English teachers who were not accustomed to use technology in a process of teaching and learning.

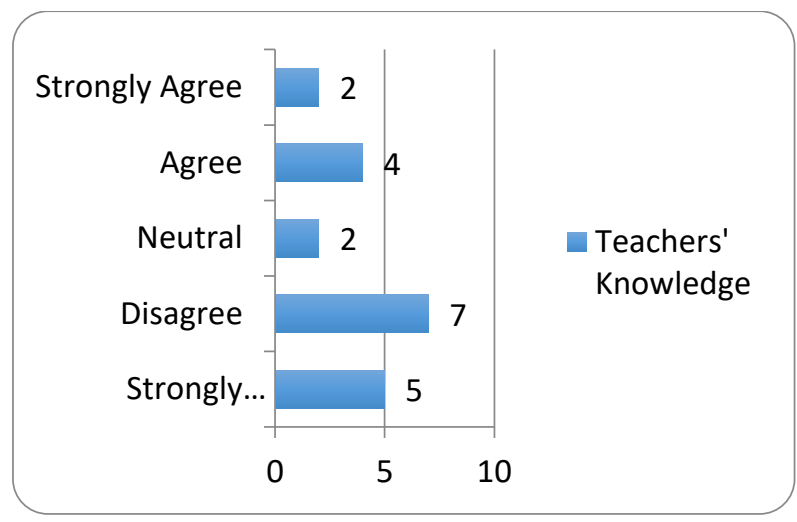

Figure 2: Pie Chart of Teachers' Knowledge

Statements from the research finding were found during the collecting data process. The participants were not confident in making HOTS assignments. This is the reason why they have not implemented it well according to the existing procedures.

"Till now, I am not sure whether what I gave to the students was HOTS or not." (FGD part 1)
"........Sometimes, I feel that HOTS concepts are not really suitable with my students in Flores.oh... or...are the teachers here ready to use HOTS? Most of the teachers even do not understand the importance of HOTS in general." (Interview, 30 July 2019)

On the other side, the participants believed that the school curriculum exerting HOTS was not so influential for the success of the learning process. Some participants were even questioning the benefits of using HOTS in teaching and learning process. There was a sense of uncertainty among the participants about the use of HOTS in every assignment that the participants gave to their students. It was not only felt by the participants. They also said that what they have stated was also experienced by the majority of English teachers in Flores, East Nusa Tenggara, Indonesia.

"I do believe that teacher Hasan important role in a process of teaching and learning, but can you imagine if the teacher does not want to develop his capability for better Education? What will happen later? I often see this condition here." (Interview, $2^{\text {nd }}$ August 2019)

Even though teachers have a crucial role in achieving the goal of success in Education, not all teachers understand their role as a teacher. That is why the participants said that they found a situation where a teacher did not want to develop himself in learning something new, for example their serious determination to attend higher order thinking skills seminar or workshop.

"Until this time, I have only once attended HOTS training. The worst thing is seeing my friends who just sit during the seminar, asked to copy the materials, busy with their own stuffs, and didn't listen to the speaker. 
I guess, they did not understand the materials at all." (FGD part 2)

“........ That is why I didn't include elements of critical Thinking, logical Thinking, problem solving and reasoning skills in every activity that I give to the students.”(Questionnaire)

This condition showed that there is no awareness among teachers about the benefits of HOTS. Then, there are participants arguing that the lack of understanding of HOTS makes them difficult to design HOTS assignments. By seeing the condition, teachers' knowledge could be said as an arduous challenge since the participants often encountered the challenge in designing HOTS assignments.

\section{Teachers' Preparation}

Teachers' preparation in teaching becomes a crucial part to consider. The situation can be likened assigners who will perform on stage and they certainly require extensive preparation such as sound effect, costumes, stage, choreography, setting and lighting before performing so that their performance will be high-quality front of the audience. Likewise, before the teachers teach in front of the class, there are a number of issues that needs to be prepared. That is why teachers' preparation is the essential part to present "an interesting show", which brings a meaningful learning process in front of the students. In the context of designing HOTS assignments, teachers' preparation is one of the significant challenges faced by English teachers, especially for the participants in Flores, East Nusa Tenggara, Indonesia.

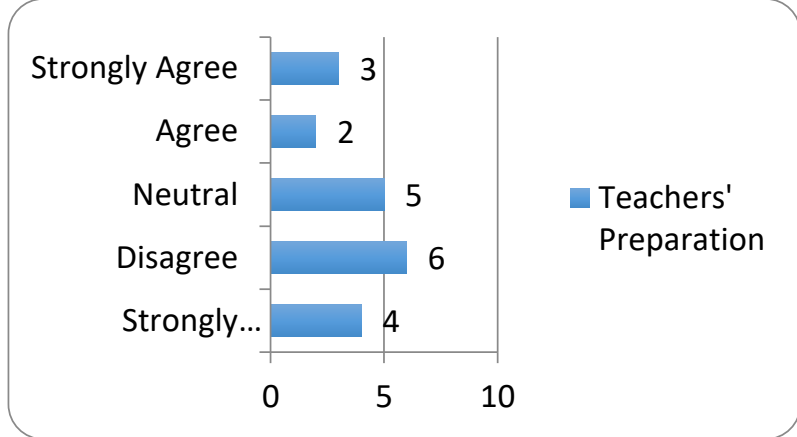

Figure 3: Pie Chart of Teachers' Preparation

The results of the pie chart above were also supported by the statements of the participants in the focus group discussion and interview.

".......for time management matter, it is very difficult for me. I must think about administration stuffs, make students' reports, attend meetings representing the school, but still being asked to make questions related to HOTS...Is there another option except for HOTS?" (FGD part 2)

“....I was already struggling to make HOTS assignments then I gave them to my students. Eeeeeeee(BundaDeo: local language which means St.Mary) students grade dropped drastically because of the HOTS assignments that I made. Feels like a boomerang!! What I prepared seriously hurt myself. Since the students got the bad score, I got warning from the headmaster and the students' parents." (Interview, 30 July 2019)

"My preparation was in vain and useless. My students without knowing HOTS can pass the final examination from the government, so I think HOTS is not a solution but I can be a burden for us, the teachers here." (Interview, $1^{\text {st }}$ August 2019) 
Based on the data collected, 50\% participants explained that their preparation in designing HOTS assignments was felt to be lacking. It was very clear in the pie chart above that $50 \%$ found challenges in terms of preparation and $25 \%$ stated neutral, signifying that they did not know what to do to design HOTS assignment. While $25 \%$ of the participants believed that they had prepared HOTS assignments well. It was very noticeable that half of the participants thought that the teachers' preparation was part of the challenges they faced.

\section{Students' Limited Ability}

Apart from the teachers' condition, students' ability was highlighted in this research finding. The participants agreed that the students' abilities were also influential in their decision in preparing HOTS assignments. Most of the participants thought that the condition and ability of students to capture the meaning of HOTS in the form of assignments have influenced their determination to prepare HOTS assignments. Most of the participants said that the students were not ready to answer HOTS questions regardless the government regulations to include HOTS questions in the national examination.

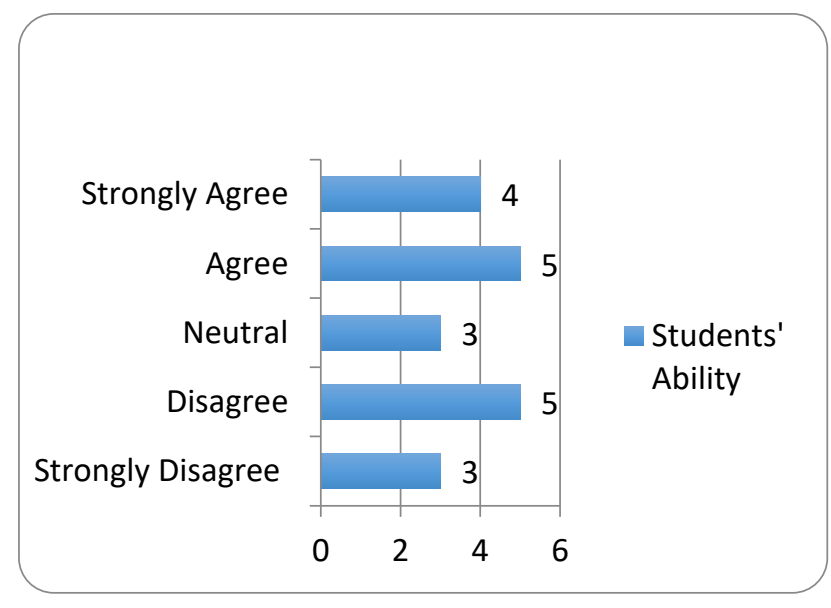

Figure 4: Pie Chart of Students' Ability

There are some surprising findings found in this research, one of which is about students' abilities. $40 \%$ of the participants had a unique discussion about students' abilities which became a challenge for them in designing HOTS assignments.

“.... HOTS are only suitable for Javanese teachers and students. It is different if we compared here." (FGD part 1)

..... The ability of students in doing nonHOTS assignments is still weak. Some of them are still experiencing difficulties. I cannot imagine how I introduce them to the HOTS assignments. Are they able to understand it? (Interview, $1^{\text {st }}$ August 2019)

Based on the research findings, the students need more exposure in doing HOTS assignments so that the students carry out HOTS awareness in their future lives. Students' ability became one of the challenges that the participants found in designing HOTS assignments. However, the condition in Flores is different. The capacity to understand HOTS may not be evenly distributed among Indonesia provinces since Indonesia is an archipelagic country. Nevertheless, it is not judicious to interpret that students in Flores are not capable enough in answering HOTS questions.

\section{Discussion}

Higher Order Thinking Skills is defined as a stimulus for the students or teachers to increase their creativity, critical thinking, and problemsolving sense (Zamani \& Rezvani, 2015). Innovation, job and technology skills are the three main components needed to achieve the main goal of $21^{\text {st }}$-century learning (Gilboy et al., 2014). These three components are linked with the core of Higher Order Thinking Skills (HOTS). However, it is still debatable whether or not HOTS can be applied in Education throughout the Indonesia Provinces. HOTS have indeed been included in some schools' curriculum in several countries (Assaly \& Smadi, 
2015) including Indonesia. A lot of efforts have been done to spread HOTS information among teachers and students. One of the challenges that the participants faced was designing HOTS assignments. Based on the results found, it can be concluded that the challenges faced by English teachers in designing HOTS assignments can be divided into three main parts. They are teachers' knowledge, teachers' preparation, and students' abilities.

The first point was about teachers' limited knowledge to apply HOTS assignments. The participants conceded that the knowledge they obtained had not met yet the standards of HOTS learning. Nevertheless, the participants have actually attended HOTS training and workshop held by the local government although this was felt to be lacking for the participants. This indicates that the local government is quite sensitive to provide teachers with the knowledge about HOTS learning, especially in designing HOTS assignments. The results of this research support what the other researchers have examined, indicating that the participants need to attend such kind of teacher professional development in order to develop their teaching competences in comprehending the instructional method to face the $21^{\text {st }}$ century learning (Gutierez, 2016).Studies in Saudi have revealed that many efforts are used to prepare teachers in designing HOTS activities related to $21^{\text {st }}$ century learning framework (Zahrani \& Elyas, 2017).The condition experienced by the participants corroborates with Benjamin Franklin's argument, "Tell me then I forget, teach me and I remember, involve me then I learn." This argument confirms that effective, engaging, and meaningful teacher professional development such as training or workshop which genuinely and deeply involves teachers was very suitable and required by the participants. An effective teacher training program cannot be defined as "one shot program" without any monitoring process since it need continuous support to improve the quality of teaching (Kuswandono, 2014). With the current educational development, there are changes that need to be harmonized with the teaching techniques given to the students and teachers in order to achieve the goals of HOTS.

The second point was about teachers' preparation which can be a "spearhead" of the "teacher energy". Regarding HOTS assignments, the participants need to understand about the core of HOTS, and then prepare the suitable activities that stimulate students' mindset into the scope of creativity and problem solving. The result of this research can be correlated to what other researchers have found. Most teachers need to improve their competence in HOTS questions by including students' creativity, problem solving and critical thinking skills (Setiawan et al., 2018) which needs time to design and prepare those skills. In this research, the participants as English teachers still found challenges to manage their time in designing HOTS assignments. Even when the participants have prepared the HOTS learning activities, it would be like a "boomerang" because the teachers should take the blame if the students were underperformed. Likewise, one participant in this research claimed that without HOTS assignments, students can even undergo the test well. Therefore, according to that participant, HOTS is not the best method for his students. Some participants also implicitly rejected the idea of HOTS because they could not assist their students to face exams given by the school or the government. This statement also confirms that the students' low ability contributes to the teachers' refusal of undertaking HOTS assignments in their English classes. This problem seems to have persisted quite a while in Flores which can be a real hurdle for the education development. Indeed, it is true that successful learning does not always rely on rigid rules imposed by the school or government, but rather on how to implement the teaching and learning process in the classroom (Purnomo et 
al., 2018). Nevertheless, teachers need to be more sensitive to the rapid changes of technology and education development which may require HOTS for the students' future needs.

Students' limited ability was the third point of the challenges faced by the participants in designing HOTS assignments. Students in this era need Higher Order Thinking Skills knowledge early to prepare them in facing the $21^{\text {st }}$ century demands(Yoke et al., 2015). Therefore, it is really high time for teachers to play their important role in preparing the students to face the future challenges (Ganapathy \& Kaur, 2014). Some participants even considered that HOTS was only suitable for Javanese teacher and students, or for other developed provinces. This notion seems to be based on the pragmatic view of the immediate test results in a standardized education rather than the long vision of learning outcomes. In contrast, a study byŞener \& Tü (2015) highlighted that the process of teaching and learning in $21^{\text {st }}$ century learning should be focused on the students cantered and project based because those activities are able to develop students' skills in facing HOTS demand. The study demonstrated that the type of studentscantered learning has not been a common practice in Flores.

Departing from this daily learning situation in Flores, teacher professional development programs can concentrate on strategies to enhance the students' confidence to initiate and be responsible for their own learning, thus proposing more on the ownership of the knowledge attainment. By so-doing, the teachers' dominance in classroom can be minimized. Students' limited ability invariably appeared to be a result of teachers' limited knowledge and preparation. By seeing this condition, it can be concluded that these three challenges; teachers' knowledge, teachers' preparation, and students' limited ability are linked to one another.

\section{CONCLUSION}

In this research, the writers discussed the perceptions of Senior High School English teachers in East Nusa Tenggara (Flores Island) regarding the challenges they faced in designing HOTS assignments. In fact, based on an anecdotal observation prior to the research, quite a number of teachers have not understood the importance of Higher Order Thinking Skills (HOTS). The research showed that all participants experienced the challenges in designing HOTS assignments which were interpreted and analysed in the research findings. There are challenges that are likely unavoidable for teachers to implement HOTS as their strategy to make their methods suitable for $21^{\text {st }}$ century learning. These challenges were classified into three parts. They are teachers' knowledge, teachers' preparation, and students' abilities. Even though the participants found the difficulties, they could regulate their emotion to maintain and develop their knowledge on Higher Order Thinking Skills (HOTS). Basically, the purpose of designing HOTS assignments was to make students ready in facing $21^{\text {st }}$ century demands. Critical thinking, logical thinking and reasoning skills are the basic components of HOTS to prepare $21^{\text {st }}$ century learning demands. However, the reality was revealed by the participants that the ideal conditions of HOTS were far from what teachers and students experienced. This condition provided the reasons why English teachers need to construct positive awareness on the importance of HOTS in designing assignments to improve the quality of English learning process.

This research was not without limitations.

For instance, the data were collected from twenty participants from East Nusa Tenggara Indonesia which might not be able to reflect the full picture of teachers' perceptions on obstacles in designing HOTS assignments. By drawing on data from questionnaire, observation, focus group discussion, and interview, future research 
can continue to explore the same topic about the challenges in designing HOTS assignments but in different research settings in Indonesia. It would also be interesting to investigate the same research by adding more participants to gain rich data. By considering the research findings, the participants need to join a workshop on how to design HOTS assignments. After attending the workshop, the teachers should be provided assistance and monitoring in each school so that HOTS workshops on HOT program can effectively progress and the teachers are able to apply HOTS in class or outside the class.

\section{REFERENCES}

Assaly, I. R., \& Smadi, O. M. (2015). Using Bloom ' $\mathrm{s}$ Taxonomy to Evaluate the Cognitive Levels of Master Class Textbook' s Questions. English Language Teaching, 8(5), 100-110. https://doi.org/10.5539/elt.v8n5p100

Creswell, J. W. (2014). Research Design: Qualitative, Quantitative, and Mixed Methods Approaches (4th ed.). Thousand Oaks: SAGE.

Faravani, A., \& Atai, M. (2015). Portfolio Assessment and the Enhancement of Higher Order Thinking through Multiple Intelligence and Dialogic Feedback. Issues in Language Teaching (ILT), 4(1), 1-25.

Ganapathy, M., Kaur, M., Singh, M., Kaur, S., \& Kit, L. W. A. I. (2017). Promoting Higher Order Thinking Skills via Teaching Practices. 3L: The Southeast Asian Journal of English Language Studies, 23(1), 75-85. https://doi.org/http://doi.org/10.17576/3L2017-2301-06 transformation

Ganapathy, M., \& Kaur, S. (2014). ESL Students' Perceptions of the use of Higher Order Thinking Skills in English Language Writing. Advances in Language and Literary Studies, 5(5), 80-87. https://doi.org/10.7575/aiac.alls.v.5n.5p.80
Gilboy, M. B., Heinerichs, S., Pazzaglia, G., \& Chester, W. (2014). Report Enhancing Student Engagement Using the Flipped Classroom. Journal of Nutrition Education and Behavior. https://doi.org/10.1016/j.jneb.2014.08.008

Gutierez, S. B. (2016). Teachers 'Reflective Practice in Lesson Study: A Tool for Improving Instructional Practice. (November 2015).

Hadi, S., Retnawati, H., Munadi, S., Apino, E., \& Wulandari, N. F. (2018). The Difficulties of High School Students in Solving Higher Order Thinking Skills Problems. Problems of Education in the 21st Century, 76(4), 520-532.

Kuswandono, P. (2014). The Fifth Biennial International Conference on Teaching and Learning of English in Asia (TLEIA5). Challenges of Teacher Certification in Indonesia, (October), 1-10.

Lea, M. R., Street, B. V, \& Lea, M. R. (2010). The " Academic Literacies " Model: Theory and Applications. (August 2013), $37-41$.

https://doi.org/10.1207/s15430421tip4504

Purnomo, Y. W., Kaur, A., \& Noor, S. (2018). The consistency between professed teaching practices and assessment practices: A case in mathematics class. Beta: Jurnal Tadris Matematika, 11(2), 101-113.

https://doi.org/10.20414/betajtm.v11i2.223

Rahman, S. A., Faridah, N., \& Manaf, A. (2017). A Critical Analysis of Bloom 's Taxonomy in Teaching Creative and Critical Thinking Skills in Malaysia through English Literature. 10(9), 245-256. https://doi.org/10.5539/elt.v10n9p245

Retnawati, H., Djidu, H., Apino, E., \& Anazifa, R. D. (2018). Teachers' Knowledge about Higher Order Thinking Skills and Its Learning Strategy. Problems of Education in the 21st Century, 76(2), 215-230. 
Şener, N., \& Tü, C. (2015). Improving Science Attitude and Creative Thinking through Science Education Project: A Design, Implementation and Assessment. Journal of Education and Training Studies, 3(4), 5767. https://doi.org/10.11114/jets.v3i4.771

Setiawan, A., Anggani, D., \& Bharati, L. (2018). Developing HOT Project-Based-Speaking Assessment to Stimulate the Students ' Critical Thinking and Creativity. English Education Journal, 8(3), 301-307.

Sulaiman, T., Muniyan, V., Madhvan, D., Ehsan, S. D., Persekutuan, W., \& Lumpur, K. (2017). International Research Journal of Education and Sciences ( IRJES ). 1(1).

Wang, S., \& Seepho, S. (2017). Facilitating Chinese EFL Learners' Critical Thinking Skills: The Contributions of Teaching Strategies. SAGE Open, (1), 1-9. https://doi.org/10.1177/2158244017734024

Yen, T. S., \& Halili, S. H. (2015). Effective Teaching of Higher Order Thinking (HOT) in Education. The Online Journal of Distance Education and E-Learning, 3(2), 41-47.

Yoke, S. K., Hasan, N. H., Jangga, R., \& Kamal, S. N. M. (2015). Innovating with HOTS for the ESL Reading Class. 8(8), 10-17. https://doi.org/10.5539/elt.v8n8p10

Zahrani, B., \& Elyas, T. (2017). The Implementation of Critical Thinking in a Saudi EFL Context: Challenges and Opportunities. Indonesian Journal of English Language Teaching and Applied Linguistics, 1(2), 133-142.

Zamani, G., \& Rezvani, R. (2015). "HOTS" in Iran $\hat{a} €^{\mathrm{TM}} \quad s$ Official Textbooks : Implications for Material Design and Student Learning. Journal of Applied Linguistics and Language Research, 2(5), 138-151. 